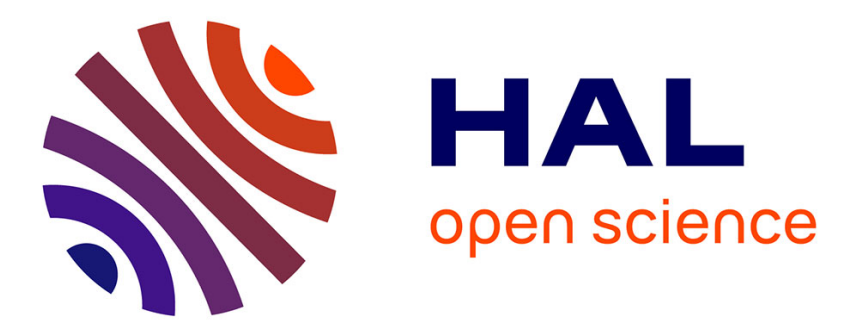

\title{
Comment on "SKS splitting beneath continental rifts zones" by Gao et al.
}

\author{
A. Vauchez, Guilhem Barruol, Adolphe Nicolas
}

\section{To cite this version:}

A. Vauchez, Guilhem Barruol, Adolphe Nicolas. Comment on "SKS splitting beneath continental rifts zones" by Gao et al.. Journal of Geophysical Research : Solid Earth, 1999, 104 (B5), pp.10787-10789. 10.1029/1999JB900053 . hal-01389720

\section{HAL Id: hal-01389720 \\ https://hal.univ-reunion.fr/hal-01389720}

Submitted on 3 Nov 2016

HAL is a multi-disciplinary open access archive for the deposit and dissemination of scientific research documents, whether they are published or not. The documents may come from teaching and research institutions in France or abroad, or from public or private research centers.
L'archive ouverte pluridisciplinaire HAL, est destinée au dépôt et à la diffusion de documents scientifiques de niveau recherche, publiés ou non, émanant des établissements d'enseignement et de recherche français ou étrangers, des laboratoires publics ou privés. 


\title{
Comment on "SKS splitting beneath continental rifts zones" by Gao et al.
}

\author{
Alain Vauchez, Guilhem Barruol, and Adolphe Nicolas \\ Laboratoire de Tectonophysique, Université de Montpellier II and NRS, Montpellier, France
}

As previously suggested by many authors, shear wave splitting measurements certainly provide the best insights on the tectonic structure (or fabric) of the upper mantle. Shear wave splitting parameters are correlated with the flow fabric developed in the deforming upper mantle. Petrophysical analysis of peridotites [e.g., Kern et al., 1996; Mainprice and Silver, 1993] shows that the largest anisotropy is recorded for shear waves propagating close to the $Y$ structural direction (i.e., normal to the lineation in the foliation plane) and that the fast split shear wave is polarized in a plane parallel to the $\mathrm{X}$ structural axis (i.e., the lineation, marked by the olivine $a$ axis concentration). Mapping shear wave splitting parameters over a specific tectonic domain would therefore provide an image of the mantle fabric at depth.

Gao et al. [1997] apply this approach to a very interesting problem: the structure and dynamics of the upper mantle beneath rift zones. From $S K S$ splitting measurements performed in three continental rifts zones (the Baikal, Rio Grande, and Kenya Rifts), they discuss the possible origin of anisotropy beneath rifts on the ground that because olivine $a$ axes tend to be preferentially oriented parallel to the extension direction, the fast shear wave polarization direction is expected to be normal to the rift. In these three rifts, however, a fast shear wave polarization direction slightly oblique or even parallel to the trend of the rift, i.e., almost orthogonal to the extension direction has been measured. To interpret this unexpected orientation, they consider several models such as lithospheric fossil anisotropy, small-scale convection cells, and aligned melt-filled cracks. Comparing their splitting data with the thermal structure suggested by seismic tomography surveys performed in these regions, Gao et al. conclude that (1) a crystallographic preferred orientation of olivine cannot develop in the flowing asthenosphere and (2) a fossil anisotropy in the lithospheric mantle would be erased at temperature above $900^{\circ} \mathrm{C}$. Hence, they suggest that the most likely source of anisotropy in the upper mantle beneath the studied rifts is the presence of melt-filled microcracks, whose preferred orientation is controlled by the state of stress in the lithosphere.

In this comment, we wish to recall the evidence supporting that (1) olivine may develop flow-induced lattice preferred orientation (LPO) under asthenospheric conditions and (2) LPO is preserved in the lithosphere even above $900^{\circ} \mathrm{C}$. As a consequence, the parallelism between the polarization azimuth of the fast split shear waves and the trend of the rift may alternatively be explained by olivine LPO either due to riftparallel asthenospheric mantle flow, to an inherited lithospheric tectonic fabric, or to a combination of both.

\section{Copyright 1999 by the American Geophysical Union.}

Paper number 1999JB900053.

0148-0227/99/1999JB900053\$09.00

\section{Development of Olivine LPO Under Asthenospheric Conditions}

Examining the possibility that a coherent crystallographic fabric was produced in the sublithospheric mantle, Gao et al. [1997, p. 22795] state that "...Such hot mantle may not develop LPO due to annealing effects such as rotational recrystallization...". In its broad metallurgical meaning, annealing is a general term which encompasses a wide variety of processes, such as recovery and grain boundary migration, that render the material softer during or after deformation. There is therefore no a priori reason for annealing to impede LPO development. Rotational recrystallization through progressive disorientation of subgrains, which occurs during dislocation creep, results in strain softening because it lowers the dislocation density in the crystal and thus allows the crystals to further deform. Dynamic recrystallization may modify but not erase the crystallographic fabric formed during the first increments of deformation, except if the new-grain size is so fine that it allows the onset of grain boundary sliding (superplasticity) as dominant deformation mechanism. In the mantle, however, this mechanism is restricted to mylonites and thus remains infrequent. Deformed mantle rocks that underwent extensive dynamic recrystallization either in natural conditions [Boudier and Coleman, 1981; Ji et al., 1994; Kern et al., 1996; Mercier and Nicolas, 1975] or during experiments [e.g., Avé-Lallemant 1975; Nicolas et al., 1973; Zhang and Karato, 1995] display a clear LPO which is either stronger [Avé-Lallemant, 1975; Zhang and Karato, 1995] or weaker [Boudier and Coleman, 1981; Nicolas et al., 1973] than the LPO of the unrecrystallized samples.

Peridotites deformed under asthenospheric conditions $\left(T \geq 1200^{\circ} \mathrm{C}\right.$, presence of melt) at mid-oceanic ridges are wellexposed in the Oman ophiolite. They certainly provide the best image of mantle material deformed under asthenospheric conditions. These samples, characterized by a large grain size $(\approx 1 \mathrm{~mm})$, usually display a strong fabric [Nicolas, 1989] probably related to the high shear strain to which the upwelling material beneath oceanic ridges is submitted. From extensive studies of ophiolites, Nicolas [1989] concludes that large-scale and homogeneous deformation representative of asthenospneric flow occurs only above $1200^{\circ} \mathrm{C}$. It may be noted that the strongest LPO are observed in dunites where grain growth was not impeded by other mineral phases. These strong fabrics may result from a selective growth of grains favorably oriented for slip.

\section{Channeled Asthenospheric Flow Below Rifts and the Fast Anisotropic Direction Parallel to the Rift}

Geochemical, petrological, and microstructural evidence ascribes an asthenospheric origin to peridotites outcropping in the 
Zabargad Island, Trinity massif, and Lanzo massif [Nicolas et al., 1994, and references herein] which likely represent the deep part of ancient rifts. In these peridotite massifs, the flow planes and flow lines (foliations and lineations), when restored to their original attitudes, are generally steeply dipping and moderately plunging, respectively, suggesting a rift-parallel mantle flow. Such observations led Nicolas [1993] to suggest that mantle flow beneath a rift may account for a fast split shear wave polarized parallel to the rift axes. Comparing these observations with the seismic tomography of the Kenya rift [Achauer et al., 1994], which shows that the low-velocity anomaly related to the hot mantle uplift is restricted to a narrow zone beneath the rift itsclf, Nicolas et al. [1994] suggested that mantle upwelling occurs within a narrow and steep conduit. At shallow depth in the mantle this flow could be progressively channeled parallel to the rift trend by the effect of the steep lithospheric shoulders. Conductive cooling along the rift walls progressively freezes the flowing asthenospheric material and its LPO. In both the frozen and actively flowing mantle the flow plane should be steep, and olivine should have its $a$ axes preferentially oriented either vertical, inducing an apparent absence of anisotropy from $S K S$ splitting, or parallel to the rift, resulting in a polarization direction of the fast split shear waves parallel to the rift. In this second case, $S K S$ waves propagate in a direction close to the $\mathrm{Y}$ structural axis, which has been described by Mainprice and Silver [1993] as the most anisotropic, and the fast split shear waves are expected to be polarized parallel to the rift. The rather strong splitting of vertically propagating $S K S$ waves reported by Gao et al. [1997] for the Kenya and Rio Grande Rifts is therefore consistent with a model of mantle flow mainly parallel to the rift. The absence of anisotropy at a few Baikal stations may be accounted by vertical flow.

\section{Preservation of Lithospheric Structures at High Temperature and Parallelism Between the Fast Anisotropic Direction in the Lithosphere and the Rift}

In their discussion, Gao et al. [1997, p. 22793] quoting Vinnik et al. [1992], assert that the "mobility of olivine crystals at temperature above $900^{\circ} \mathrm{C}$ is high and therefore the survival of fossil anisotropy is very unlikely in the mantle beneath rifts". The physical meaning of the enhanced mobility of olivine above $900^{\circ} \mathrm{C}$ is that above this temperature, mantle rocks are able to deform through dislocation slip and climb under deviatoric stress higher than the yield strength of the rock [e.g., Nicolas and Poirier, 1976]. If the deviatoric stress is too low, there will be no deformation and the fossil LPO is kept. If it is high enough for the rock to deform, a new LPO will develop. As a matter of fact, the deviatoric stress necessary to deform olivine aggregates at $900^{\circ} \mathrm{C}$ and strain rates $\geq 10^{-15} \mathrm{~s}^{-1}$, computed using experimental data [e.g., Chopra and Paterson, 1981], is higher than $100 \mathrm{MPa}$; a value so high that the deformation is confined to restricted areas within the lithosphere.

Natural samples of lithospheric mantle rocks, either from peridotite massifs or from xenoliths brought up to the surface by kimberlitic or basaltic volcanism, clearly rule out the concept of LPO erasing above $900^{\circ} \mathrm{C}$. LPO have been measured for a large number of continental and oceanic samples equilibrated in the lithosphere at temperatures higher than $900^{\circ} \mathrm{C}$. The presence of a well-defined olivine crystallographic fabric, clearly distinguishable from reworking related with extraction or emplacement processes, is a rule [Barruol and Kern, 1996; Boudier and Coleman, 1981; Ji et al., 1994; Kern et al., 1996; Mainprice and Silver, 1993; Mercier and Nicolas, 1975]. Kern et al. [1996], for instance, have measured and calculated the intrinsic seismic anisotropy of mantle xenoliths sampled in the Vitim volcanic area, east of the Baikkal rift zone (zone E of Gao et al. [1997]). The source depth and equilibration temperature of these xenoliths are in the range $40-90 \mathrm{~km}$ and $800-1000^{\circ} \mathrm{C}$. These samples display a LPO of olivine that produces a seismic anisotropy of 5-6.6\% for $P$ waves and 3.1-4.75\% for $S$ waves, in agreement with anisotropy values and patterns obtained from others continental domains. The study of lithospheric mantle xenoliths leads to the conclusion that although these rocks have been maintained at temperature up to $1000-1100^{\circ} \mathrm{C}$ for a long time, they have retained a LPO sufficiently large to generate a significant seismic anisotropy.

Assuming that the lithospheric structures were erased by the upwelling hot mantle, Gao et al. discard the model that a frozen lithospheric structure may represent the main source of the splitting they have observed beneath and beyond rift shoulders. Gao et al. [1997, p.22793] mentioned that "each rift zone was the site of continental convergence prior to rifting." It should be added to this statement that in the three studied domains, rifting occurred parallel to an old orogenic fabric (e.g., see review in Vauchez et al. [1997]). It was previously suggested [e.g., Silver, 1996; Silver and Chan, 1988; Vauchez and Barruol, 1996; Vauchez and Nicolas, 1991] that during major orogenic events a pervasive tectonic fabric develops in the mantle and that this fabric, frozen when the thermal regime of the orogenic area is relaxed to normal, subsequently represents a major source of the seismic anisotropy of continents. Beyond shear wave splitting, the existence of a coherent fabric in the lithospheric mantle is also supported by Pn [Hearn, 1996] and surface waves [e.g., Babuska et al., 1998] anisotropy and by electrical conductivity anisotropy (magnetotelluric soundings [e.g., Sénéchal et al., 1996]). This fossil fabric was also invoked as a source of mechanical anisotropy for the lithosphere, which may have favored a propagation of rifting parallel to the orogenic grain of continental domains [Vauchez et al., 1997]. According to this model, although the preexisting lithospheric fabric may be progressively weakened where the lithosphere is thinned and replaced by flowing asthenospheric mantle, an inherited signature could be retained beyond the active part of the rift at least. The data presented by Gao et al. [1997] stand in good agreement with this expectation. For instance, the fast shear wave polarization measured east of the Kenya rift parallels the tectonic fabric of the Mozambique belt, especially major transcurrent shear zones (compare structural maps of Shackleton [1996] andismith and Mosley [1993D, frozen since Panafrican times. Similarly, the polarization of the fast split shear waves in zone $F$ of the Baikal Rift tends to parallel the orogenic fabric of the Transbaikal belt [e.g., Ufimtsev, 1990]. Although a contribution to seismic anisotropy due to the presence of oriented melt pockets cannot be ruled out in these areas, shear wave splitting may predominantly reflect the deep lithospheric fabric frozen since the formation of the Mozambique or the Siberian-Mongolian belts. A lithospheric origin would also account for the seismic anisotropy measured on the Siberian craton relatively far from the rift boundary.

\section{Conclusions}

In previous papers we have emphasized that shear wave splitting in a specific area may be due to a mantle fabric resulting 
from superimposed events and that a detailed examination of the geodynamic evolution of the probed area is necessary to infer the possible sources of seismic anisotropy [Barruol et al., 1997; Nicolas, 1993; Vauchez and Barruol, 1996; Vauchez and Nicolas, 1991]. Shear wave splitting may be generated at various depths [e.g., Montagner, 1998]. The scope of this comment is not to discuss all possible contributions to seismic anisotropy but rather to show that (1) a crystallographic fabric may be retained in the lithosphere over long period of time, even at high temperature, and (2) a crystallographic fabric may form during mantle deformation under asthenospheric condition. We do agree that a preferred orientation of melt pockets parallel to mantle flow beneath rifts is likely and may participate to the total observed anisotropy when the fast split shear wave is polarized parallel to the rift axes. Geological evidence of such melt pockets were already described for instance in the Lanzo peridotites in the Alps [Boudier, 1978] where plagioclase clusters, representing the paleoliquid phase, are organized parallel to the foliation plane. Petrophysical computation of anisotropic seismic properties in partially molten mantle rocks supports that aligned melt pocket may generate a significant seismic anisotropy [Mainprice, 1997]. However, this contribution to become dominant would require several percent of melt concentrated in coherently aligned melt pockets displaying a high aspect ratio. Moreover, the asthenospheric wedge beneath the rift axis, where melting may occur, is usually narrow [Nicolas et al., 1994]. Consequently, a large volume of preferentially oriented melt pockets is unlikely beyond the ridge axis, especially beneath rift shoulders.

Alternative, and more likely, models may satisfactorily account for the fast shcar waves polarization parallel or slightly oblique to the rift structures reported by Gao et al. [1997]:

1. Longitudinally channeled mantle flow, resulting in the development of a steep foliation and a subhorizontal lineation, is certainly the rule in continental rifts and probably also at slow spreading oceanic ridges, especially when mantle upwelling occurs in a steep and narrow conduit. A LPO characterized by a preferential orientation of olivine $a$ axes parallel to the rift should develop in the hot flowing mantle, and this LPO will be frozen at rift walls during rift opening.

2. Frozen LPO formed during major past orogenies may be retained in the lithospheric mantle over long time periods, even at high temperature as far as the lithosphere is not deformed again. An inherited lithospheric structure is certainly preserved beneath the shoulders of the rift and outside the active domain and may induce shear wave splitting with a fast polarization direction parallel to both the prerift orogenic fabric and the rift itself.

Acknowledgements: We are indebted to D. Mainprice and A. Tommasi for useful discussions and suggestions. Reviews from L.P. Vinnik and H. R. Wenk are gratefully acknowledged.

\section{References}

Achauer, U., and the KRISP Teleseismic Working Group, New ideas on the Kenya rift based on the inversion of the combined dataset of the 1985 and 1989/90 seismic tomography experiments, Tectonophysics, 236, 305-329, 1994.

Avé-Lallemant, H.G., Mechanisms of preferred orientations in olivine in tectonite peridotites, Geology, 3, 653-656, 1975.

Babuska, V., J.P. Montagner, J. Plomerova, and N. Girardin, Agedependent large-scale fabric of the mantle lithosphere as derived from surface-wave velocity anisotropy, Pure Appl. Geophys., 151, 257-280, 1998.

Barruol, G., and H. Kern, Seismic anisotropy and shear-wave splitting in lower-crustal and upper-mantle rocks from the Ivrea zoneExperimental and calculated data, Phys. Earth Planet. Inter., 95, 175194, 1996

Barruol, G., P.G. Silver, and A. Vauchez, Seismic anisotropy in the eastern United States: Deep structure of a complex continental plate, J. Geophys. Res., 102, 8329-8348, 1997.

Boudier, F., Structure and petrology of the Lanzo massif (Piedmont Alps)., Geol. Soc. Am. Bull., 89, 1574-1591, 1978.

Boudier, F., and R.G. Coleman, Cross section through the peridotites in the Samail ophiolite, southeastern Oman, J. Geophys. Res., 86, 2573$2592,1981$.

Chopra, P.N., and M.S. Paterson, The experimental deformation of dunite, Tectonophysics, 78, 453-473, 1981.

Gao, S., P.M. Davis, H. Liu, P.D. Slack, W. Rigor, Y.A. Zorin, V.V. Mordvinova, V.M. Kozhevnikov, and N.A. Logatchev, SKS splitting beneath continental rift zones, J. Geophys. Res., 102, 22781-22797, 1997.

Hearn, T.M., Anisotropic Pn tomography in the western United States, $J$. Geophys. Res., 101, 8403-8414, 1996.

Ji, S., X. Zhao, and D. Francis, Calibration of shear-wave splitting in the subcontinental upper mantle beneath active orogenic belts using ultramafic xenoliths from the Canadian cordillera and Alaska, Tectonophysics, 239, 1-27, 1994.

Kern, H., L. Burlini, and I.V. Ashchepkov, Fabric-related seismic anisotropy in upper-mantle xenoliths: Evidence from measurements and calculations, Phys. Earth Planet. Inter., 95, 195-209, 1996.

Mainprice, D., Modeling the anisotropic seismic properties of partially molten rocks found at mid-ocean ridges, Tectonophysics, 279, 161179, 1997.

Mainprice, D., and P.G. Silver, Interpretation of SKS-waves using samples from the subcontinental lithosphere, Phys. Earth Planet. Inter., 78, 257-280, 1993.

Mercier, J.-C., and A. Nicolas, Textures and fabrics of upper mantle peridotites as illustrated by xenoliths from basalts, J. Petrol., 16, 454487, 1975 .

Montagner, J.P., Where can seismic anisotropy be detected in the Earth's mantle? In boundary layers..., Pure Appl. Geophys., 151, 233-256, 1998.

Nicolas, A., Structures of Ophiolites and Dynamics of Oceanic Lithosphere, 367 pp., Kluwer Acad., Norwell, Mass., 1989.

Nicolas, A., Why fast polarization directions of $S K S$ seismic waves are parallel to mountain belts?, Phys. Earth Planet. Inter., 78 , 337-342, 1993.

Nicolas, A., and J.P. Poirier, Crystalline Plasticity and Solid State Flow in Metamorphic Rocks, 444 pp., John Wiley, New York, 1976.

Nicolas, A., F. Boudier, and A.M. Boullier, Mechanism of flow in naturally and experimentally deformed peridotites, Am. J. Sci., 273, 853-876, 1973.

Nicolas, A., U. Achauer, and M. Daignieres, Rift initiation by lithospheric rupture, Earth Planet. Sci. Lett., 123, 281-298, 1994.

Sénéchal, G., S. Rondenay, M. Mareschal, J. Guilbert, and G. Poupinet, Seismic and electrical anisotropies in the lithosphere across the Grenville Front, Canada, Geophys. Res. Lett., 23, 2255-2258, 1996.

Shackleton, R.M., The final collision zone between East and West Gondwana: Where is it?, J. Afr. Earth Sci., 23, 271-287, 1996.

Silver, P.G., Seismic anisotropy beneath the continents: Probing the depths of geology, Annu. Rev. Earth Planet. Sci., 24, 385-432, 1996.

Silver, P.G., and W. Chan, Implications for continental siructure and evolution from seismic anisotropy., Nature, 335, 34-39, 1988.

Smith, M., and P. Mosley, Crustal heterogeneity and basement influence on the development of the Kenya Rift, Tectonics, 12, 591-606, 1993.

Ufimtsev, G.F., Morphotectonics of the Mongolian-Siberian mountain belt, J. Geodyn., 11, 309-325, 1990.

Vauchez, A., and G. Barruol, Shear waves splitting in the Appalachians and the Pyrenees: Importance of the inherited tectonic fabric of the lithosphere, Phys. Earth Planet. Inter., 95, 127-138, 1996.

Vauchez, A., and A. Nicolas, Mountain building: Strike-parallel displacements and mantle anisotropy, Tectonophysics, 185, 183-201, 1991.

Vauchez, A., G. Barruol, and A. Tommasi, Why do continents break up parallel to ancient orogenic belts?, Terra Nova, 9, 62-66, 1997.

Vinnik, L.P., L.I. Makeyeva, A. Milev, and A.Y. Usenko, Global patterns of azimuthal anisotropy and deformations in the continental mantle, Geophys. J. Int., 111, 433-437, 1992.

Zhang, S., and S. Karato, Lattice preferred orientation of olivine aggregates in simple shear, Nature, 375, 774-777, 1995.

G. Barruol, A. Nicolas, and A. Vauchez, Laboratoire de Tectonophysique, Université de Montpellier II, Place Eugène Bataillon, 34095 Montpellier cedex 5, France. (vauchez@dstu.univ-montp2.fr)

(Received January 20, 1998; revised June 10, 1998;

accepted January 15, 1999) 